https://doi.org/10.31713/m1006

\title{
PRINCIPLES OF OPTIMIZATION OF THE FUEL AND ENERGY COMPLEX BASED ON MINIMIZING THE DESTRUCTIVE IMPACT ON THE ENVIRONMENT
}

Kovshun N.E.

National University of Water and Environmental Engineering, Professor, Doctor of Economic Science, Professor, Department of Finance and Economic Security, Ukraine

\section{Moshchych S.Z.}

National University of Water and Environmental Engineering, Candidate of Economic Sciences, Senior Lecturer of the Institute of Postgraduate Education, Ukraine

Malanchuk L.O.

National University of Water and Environmental Engineering, Candidate of Economic Sciences, Associate Professor, Associate Professor of the Department of Public Administration, Documentation and Information Activity, Ukraine

\section{Kostrychenko V.M.}

National University of Water and Environmental Engineering, Candidate of Economic Sciences, Associate Professor, Associate

Professor of the Department of Business Economics and International Business, Ukraine

\section{Veretin L.S.}

National University of Water and Environmental Engineering, Candidate of Economic Sciences, Senior Lecturer of the Institute of Postgraduate Education, Ukraine

\section{Summary}

In the context of the social and economic crisis, the energy sector plays a strategic role in terms of Ukraine's sectorial structure: filling the budget, additional export revenues, and other economic and social benefits. However, further exploitation of existing technologies for extraction, transportation and conservation of mineral resources has a negative impact on the environment, which ultimately leads to a loss of quality of energy resources themselves. 
Achieving the goals set by the Energy Strategy of Ukraine until 2035, as well as other sectorial programs, among which integration into European energy markets is important, requires large-scale modernization and reform.

The subject of the research is the methodological principles of bi-criteria substantiation of investments in energy projects, which provide for the assessment of the economic feasibility of such projects taking into account the possible environmental consequences.

The research methodology includes consideration of methodological bases of ecological regulation of national energy development in the conditions of implementation of European ecological requirements, analysis of conditions of achievement of strategic priorities of national economy development, formalization of methodical bases of substantiation of investments in energy projects using multivariate approach.

The purpose of the study is to develop an algorithm for economic and environmental justification of investments in energy projects, taking into account environmental impacts and economic interests of energy market participants.

The conducted research, in order to solve the outlined problems of the branch, requires the implementation of the proposed practical recommendations of bringing the ecological regulation of the national energy complex to the requirements of the European Energy Community.

\section{Introduction}

Ukrainian energy has significant potential for attracting investment. The investment process has an important impact on structural changes and aims to respond flexibly to changes in the volume and structure of needs and to influence the volume and structure of production in the appropriate direction [1]. However, for a long time, the industry lacked transparent, competitive and clear rules of the game for market participants, monopolies and overregulation. This hindered the progressive development and modernization of the Ukrainian energy sector. And the system of cross-subsidization and subsidies from the budget restrained the growth of energy prices for the population, at the same time laundering huge funds, creating unequal conditions, hindering modernization and development, introduction of new technologies at fuel and energy enterprises.

The reform of the energy sector aims to bring it to a fundamentally new, high-quality level of development, bring it in line with EU norms and standards, liberalize and form full-fledged natural gas and electricity markets with transparent and competitive pricing and adequate protection of vulnerable consumers. These 
actions are also designed to optimize the energy balance and increase economic, energy and environmental security.

General approaches to reforming Ukraine's energy sector have been studied by domestic scientists, international experts and institutions. At the same time, as numerous studies show, in the modern practice of diversification of sources of production and supply of natural gas from traditional and non-traditional sources, there is mostly no comprehensive approach to environmentally regulated optimization of energy projects.

The purpose of the study is to develop an algorithm for economic and environmental justification of investments in energy projects, taking into account environmental impacts and economic interests of energy market participants.

To achieve this goal, the study solved the following tasks: revealed the methodological principles of environmental regulation of national energy in the implementation of European environmental requirements, analyzed the conditions for achieving strategic priorities of the national economy, formalized the methodological principles of investment in energy projects, developed practical recommendations for bringing the environmental regulations of the national energy complex to the requirements of the European Energy Community.

The study contains elements of scientific novelty, in particular, the proposed method of environmentally regulated optimization, which is universal and is a tool for analyzing the interaction of society and nature in the implementation of production activities, which is inevitably accompanied by man-made environmental impact. The result of such an analysis is an economically and environmentally sound decision on the feasibility or inexpediency of implementing energy projects.

\section{Environmental economic research}

The rapid growth of energy consumption creates the danger of a rapid depletion of energy resources. In addition, the dynamics of world energy consumption indicates its exponential growth, which is a potential threat of increasing excessive heat emissions, which can disrupt the thermal balance of the planet and lead to catastrophic changes in its climate. Therefore, the development of national energy using the methods of environmental regulation will contribute to the 
sustainable development of fuel and energy. We believe that the key element of such development is ecologically regulated optimization $[2 ; 10]$.

Under the ecologically regulated optimization of the fuel and energy complex we understand its restructuring on the principles of systemic minimization of the destructive impact of energy-producing technologies on the environment and on its main element - man with the use of methods of ecological regulation.

It is clear that energy in its essence has never been and will not be completely environmentally friendly [11]. Even renewable energy sources in their large-scale application give a predictable or unpredictable, not only positive but also negative effect.

The reform of the energy sector aims to bring it to a fundamentally new, high-quality level of development, bring it in line with EU norms and standards, liberalize and form full-fledged natural gas and electricity markets with transparent and competitive pricing and adequate protection of vulnerable consumers $[5 ; 8]$.

It should be emphasized that in companies that manage privatized or transferred to the management of fuel and energy enterprises, when drawing up business plans, the obligatory main section is environmental optimization, which provides a set of well-founded and certainly appropriate measures (reduction of unproductive costs, sale of non-core assets, increasing productivity, etc.). However, companies tend to ignore the increase in the cost of environmental measures, and in some cases even allow them to be reduced to reduce production costs. Therefore, the signing of Ukraine's association agreement with the EU and the long-term task of achieving full membership in it should put an end to such environmentally destructive and harmful to society approaches in public fuel and energy management and business by Ukrainian fuel and energy entities $[12 ; 13]$. Without taking into account the environmental component, it is impossible to hope for real integration with the European Union. Therefore, environmentally regulated optimization as an approach to management in the fuel and energy sector should become dominant at all levels - national, regional, level of the business entity.

Economic and environmental levers must be mutually taken into account and balanced. No effective economic solution should be 
considered without taking into account the possible environmental consequences [6]. Only such an approach to the functioning and development of fuel and energy will ensure socio-economic and political stability in the country. The proposed method of environmentally regulated optimization of fuel and energy involves the use of multifactor analysis of production processes (technological, environmental, economic, socio-political) with the obligatory dominance of the environment (production, which results in irreversible negative environmental changes, have no right to exist; or liquidation in general, fundamentally new productions should not initiate the creation of new, not previously fixed and technologically uncompensated environmental problems).

The management practice of diversification of gas supply sources in the context of ensuring Ukraine's energy security and reforming its energy markets is considered on the example of the gas production market. Proven reserves of traditional gas allow keeping annual production in the range of 20-23 billion cubic meters with a tendency to insignificant growth (subject to investment). According to the United States Agency for International Development (USAID), in the case of the development of Ukraine's fuel and energy sector while maintaining current trends and government policy, moderate investment in the gas industry will increase traditional gas production to 23.5 billion cubic meters in 2025 and 25.7 billionm $^{3}$ in 2030. The main increase in natural gas production in Ukraine in the future, according to USAID, can be achieved due to non-traditional types of gas, which in Ukraine include gas of dense rocks; shale gas; methane from coal deposits. Note that the exploration of these types of gas in Ukraine is at an early stage, none of these types is still being extracted. Due to the lack of accurate geological data on the reserves of unconventional gas, there is still significant uncertainty about the possible volume and cost of unconventional gas production.

Taking into account the method of ecologically regulated optimization, we will analyze the possibility of extracting in Ukraine the most realistic in terms of available technologies varieties of unconventional gas - the so-called gas of dense rocks and shale gas. On the territory of Ukraine, two promising regions with deposits are considered: dense gas Dnieper-Donetsk (Eastern Ukraine) and shale 
gas Lublin (Western Ukraine) with reserves of 1.4 trillionm $^{3}$ and 4.2 trillionm ${ }^{3}$, respectively.

Analysis of the specifics of dense gas and shale gas in terms of technological, environmental, economic factors leads to the conclusion that there is a significant environmental risk of extracting this energy at the current technological level and the lack of convincing arguments for greater economic efficiency compared to traditional gas.

However, the curtailment of work to prepare for unconventional gas production in 2015 took place not only in Ukraine but also in other European countries, where such work was carried out: in Poland, Lithuania, Romania, Bulgaria. The list of reasons for the curtailment of work on unconventional gas in Ukraine includes the increase in 2014 of rent for gas production to 50-60\%, careful public monitoring of the state of the environment [9]. However, the priority reason is the fall in world prices for energy hydrocarbons.

To formalize the understanding of attempts to transform the gas market of Ukraine, we will use the possibilities of situational analysis. Thus, the tool for transforming the gas market was investing in the production of a new energy product - unconventional gas. This process allowed meeting the needs of three parties - the government, the public, the investor. At the same time, the ecological impact on the environment was carried out, which had to be assessed in accordance with the normatively permissible levels. The end result is the extracted gas, the price of which was formed depending on the costs incurred by the investor and compared with the price level in the current market.

For formula display, enter the appropriate notation: $P_{v}$ - needs of the government; $P_{s}$ - the needs of society; $P_{i}$ - the needs of the investor; $\mathrm{EV}_{\text {norm }}$ - the total environmental impact on the environment from the use of unconventional gas production technology, allowed by the standards established in Ukraine; $\mathrm{EV}_{\text {fact }}$ - the actual environmental impact on the environment from the use of unconventional gas production technology; $C_{r}$ - the current market price for gas in the relevant market of Ukraine; These are the price of extracted unconventional gas set by the investor. 
Possible options for the development of the situation with the extraction of unconventional gas are presented in the form of a matrix of situational analysis (table 1).

The study used a multivariate approach that allows you to model the layout of different situations in the process of transformation of the gas market.

And the option (optimistic) can be described as follows.

The technology of unconventional gas extraction has created an actual ecological impact on the environment not higher than the standards allowed in Ukraine $\left(\mathrm{EV}_{\text {fact }} \leq \mathrm{EV}_{\text {norm }}\right)$.

The costs of the investor (cost of production) allow him to set a competitive price for the received unconventional gas $\left(C_{i} \leq C_{r}\right)$.

The needs of the investor, the government and society regarding the extraction of unconventional gas are generally met $\left(P_{i}=P_{v}=P_{s}\right)$.

The investor has an interest and the opportunity to plan the continuation of work on the extraction of unconventional gas and expand its market.

Table 1

Matrix of formalized situational analysis of transformation of the gas production market of Ukraine

\begin{tabular}{|c|c|c|c|c|}
\hline \multirow[t]{2}{*}{ Situation } & \multirow{2}{*}{$\begin{array}{c}\text { I option } \\
\text { (optimistic) }\end{array}$} & \multirow{2}{*}{$\begin{array}{c}\text { II option } \\
\text { (pessimistic) }\end{array}$} & \multicolumn{2}{|c|}{ III option (unbalanced) } \\
\hline & & & Scenario 1 & Scenario 2 \\
\hline $\begin{array}{l}\text { The technology } \\
\text { of unconventional } \\
\text { gas production } \\
\text { has created an } \\
\text { actual } \\
\text { environmental } \\
\text { impact on the } \\
\text { environment }\end{array}$ & $\mathrm{EV}_{\text {fact }} \leq \mathrm{EV}_{\text {norm }}$ & $\mathrm{EV}_{\text {fac }} \geq \mathrm{EV}_{\text {norm }}$ & $E V_{\text {fact }} \geq E V_{\text {norm }}$ & $\begin{aligned} & E V_{\text {fact }} \\
\leq & E V_{\text {norm }}\end{aligned}$ \\
\hline $\begin{array}{l}\text { The investor's } \\
\text { costs (production } \\
\text { cost) allow him to } \\
\text { set the price of } \\
\text { unconventional } \\
\text { gas }\end{array}$ & $C_{i} \leq C_{r}$ & $C_{i} \geq C_{r}$ & $C_{i} \leq C_{r}$ & $C_{i} \geq C_{r}$ \\
\hline $\begin{array}{l}\text { The needs of the } \\
\text { investor, the } \\
\text { government and } \\
\text { society regarding } \\
\text { the extraction of } \\
\text { unconventional } \\
\text { gas }\end{array}$ & $P_{i}=P_{v}=P_{s}$ & $P_{i} \neq P_{v} \neq P_{s}$ & $\begin{array}{l}P s \neq P i \\
P s=P v \\
P v \neq P s\end{array}$ & $\begin{array}{l}P v \neq P_{s} \\
P_{v}=P_{s}\end{array}$ \\
\hline
\end{tabular}

Source: compiled by the authors 
II option (pessimistic) can be described as follows.

The technology of unconventional gas extraction has created an actual ecological impact on the environment above the standards allowed in Ukraine $\left(\mathrm{EV}_{\text {fact }} \geq \mathrm{EV}_{\text {norm }}\right)$.

The costs of the investor (cost of production) do not allow him to set a competitive price for the unconventional gas $\left(C_{i} \geq C_{r}\right)$.

The needs of the investor, the government and society regarding the extraction of unconventional gas are not met $\left(P_{i} \neq P_{v} \neq P_{s}\right)$.

The investor has no economic interest in continuing to produce unconventional gas.

Option III (unbalanced) can be described in two scenarios as follows.

Scenario 1: the technology of unconventional gas production has created an actual environmental impact on the environment above the permitted standards in Ukraine $\left(\mathrm{EV}_{\text {fact }} \geq \mathrm{EV}_{\text {norm }}\right)$.

At the same time, the investor's costs (production cost) allow him to set a competitive price for the received unconventional gas $\left(C_{i} \geq C_{r}\right)$.

The needs of the parties are in a more complex interaction:

$a-P_{s} \neq P_{i}$ - the needs of society come into conflict with the needs of the investor; in the case of $P_{s}=P_{v}$, ie the identity of the interests of society and government, the investor is forced to increase the cost of environmental measures to reduce $\mathrm{EV}_{\text {fact, }}$, but this automatically leads to an increase in Qi and minimize profits.

$b-P_{v} \neq P_{s}$ (which is typical for the current state of affairs in Ukraine) - the government is forced to manipulate public opinion, to ignore it, while exposing it to the threat of a social explosion, in order to interest investors in continuing work without changing technology.

Scenario 2: the technology of unconventional gas production has created an actual environmental impact on the environment below the standards allowed in Ukraine $\left(\mathrm{EV}_{\text {fact }} \leq \mathrm{EP}_{\text {norm }}\right)$.

At the same time, the investor's costs (production cost) do not allow him to set a competitive price for the received unconventional gas $\left(C_{i} \geq C_{r}\right)$.

The options for the parties may be as follows: the investor reduces the cost of environmental needs, thereby increasing $\mathrm{EV}_{\text {fact }}$ (without exceeding or exceeding $\mathrm{EV}_{\text {norms }}$ ) to achieve $T_{i} \leq C_{r}$ (to ensure 
a competitive price). In the case of $P_{v} \neq P_{s}$, the government will simply not control the increase in $\mathrm{EV}_{\text {fakt }}$ and will allow the investor to reach a competitive price under any conditions, receiving the threat of social protests. In the case of $P_{v}=P_{s}$ by constant monitoring will be provided $\mathrm{EV}_{\text {fact }} \leq \mathrm{EV}_{\text {norm, }}$, but the authorities will have to resort to subsidizing the sale of unconventional gas under the conditions of $C_{i} \geq C_{r}$.

Immediately note that we consider the probability of scenario 2 of option III (unbalanced) to be extremely low. Analysis of the activities of unconventional gas companies in the United States, Canada, Great Britain, and West Africa confirms in almost all cases the construction of business plans according to the situational scheme of scenario 1 of option III. That is, the investor (while partially ignoring the environmental impact) achieved a competitive price for the extracted unconventional gas, ignoring, as far as possible, public protests. The authorities acted differently in each case, but in general, for global political reasons (to assist national investors in the struggle for the world gas market), they maintained, so to speak, positive neutrality.

The trend of the Central Bank to a significant decline has made it impossible for investors to produce unconventional gas. This explains the contraction of unconventional gas production in Eastern Europe, including Ukraine, which was the result of investors' forecasting of the future situation in accordance with the second option (pessimistic).

The situational analysis (according to the proposed method of environmentally regulated optimization) of attempts to transform the gas production market of Ukraine is based on a comprehensive approach to the object of study and makes it possible to reveal the degree and direction of the main factors.

The proposed method of environmentally regulated optimization is universal. It allows you to analyze the interaction of society and nature in the implementation of production activities, which is inevitably accompanied by man-made pressure on the environment. As a result of such analysis, a bi-criteria decision can be made (according to economic and environmental parameters) on the feasibility or inexpediency of implementing certain programs, business projects, etc. 
Given the technological level of fuel and energy, the total need for innovative financing (according to experts) is from 8 to 12 billion UAH annually.

Businesses will not be able to obtain such financial resources on their own without targeted foreign investment. Therefore, the problem of creating an attractive investment climate in the fuel and energy sector of Ukraine to intensify innovation processes has become especially important.

As noted by the specialists of the National Institute for Strategic Studies, to increase the investment attractiveness of the innovation market of the fuel and energy complex of Ukraine, it is necessary to perform a consistent set of measures, which are summarized in Table 2.

An objective indicator of the effectiveness of innovation in the fuel and energy sector, taking into account the requirements of environmental regulations should be the achievement of certain levels of basic indicators that characterize the efficiency of the fuel and energy sector and its impact on the environment.

As an option for a possible assessment, we offer a set of parameters listed in Table 3, formed using data from the National Institute for Strategic Studies.

Achieving these levels of basic indicators requires not only the intensification of investment activities.

Ultimately, the environmental regulation of the fuel and energy sector (as well as other sectors of the economic complex) requires the construction of a new system of relationships in the chain: central government - regional government (local government) - the business entity.

However, the dominant role of the central government in the implementation of the system of environmental regulation and control over this process objectively encountered insurmountable difficulties in the current conditions, namely: the lack of effective and objective environmental monitoring; unsatisfactory control over the implementation of state environmental programs and a formal approach to monitoring the implementation of regional environmental programs. 
Measures to create an attractive investment climate in Ukraine's fuel and energy sector

\begin{tabular}{|c|c|}
\hline Stages & Contents of the stage \\
\hline \multirow{7}{*}{$\begin{array}{l}\text { I stage - } \\
\text { until } \\
2025\end{array}$} & $\begin{array}{l}\text { 1. Formation of a system of support for the introduction of energy technologies } \\
\text { and management systems (stimulation of the introduction of innovative } \\
\text { technologies), creation of a system of scientific and technical centers for } \\
\text { technology development, research and development of energy potential } \\
\text { (grants, scholarships, funding for study abroad). }\end{array}$ \\
\hline & 2. Providing financial support for basic and applied research. \\
\hline & $\begin{array}{l}\text { 3. Approval of the methodology for estimating the cost of capital, which can be } \\
\text { taken into account for the formation of tariffs for products and services for } \\
\text { various sectors of the fuel and energy sector. }\end{array}$ \\
\hline & $\begin{array}{l}\text { 4. Formation of a national network of energy technology transfer, state support } \\
\text { of technology transfer (technology purchase), localization of energy } \\
\text { technology production. }\end{array}$ \\
\hline & $\begin{array}{l}\text { 5. Introduction of new specialties for the energy sector and new training } \\
\text { programs for specialists in educational institutions in order to train staff to } \\
\text { work in energy markets. }\end{array}$ \\
\hline & $\begin{array}{l}\text { 6. Introduction of a system of advanced training of specialists on the } \\
\text { implementation of energy management systems, use of renewable energy } \\
\text { equipment. }\end{array}$ \\
\hline & $\begin{array}{l}\text { 7. Updating the material and technical base of scientific institutions and } \\
\text { institutions of higher education, which provide training for fuel and energy }\end{array}$ \\
\hline \multirow{3}{*}{$\begin{array}{l}\text { II stage } \\
\text { - until } \\
2030\end{array}$} & $\begin{array}{l}\text { 1. Ensuring the participation of domestic research institutions in scientific and } \\
\text { technological programs of the EU and the approximation of Ukraine to the } \\
\text { European scientific space. }\end{array}$ \\
\hline & $\begin{array}{l}\text { 2. Introduction of an investment risk insurance instrument within the } \\
\text { framework of the mechanism for supporting the implementation of innovative } \\
\text { projects in the energy sector (Energy Development Fund). }\end{array}$ \\
\hline & $\begin{array}{l}\text { 3. Formation of a system of support for venture activity and transfer of energy } \\
\text { technologies, development of Ukrainian engineering companies. }\end{array}$ \\
\hline \multirow{3}{*}{$\begin{array}{l}\text { stage - } \\
\text { until } \\
2035\end{array}$} & $\begin{array}{l}\text { 1. Creation of national energy companies and support for their entry into } \\
\text { foreign markets. }\end{array}$ \\
\hline & $\begin{array}{l}\text { 2. Implementation of pilot projects for carbon capture and storage, processing } \\
\text { of household waste, etc. }\end{array}$ \\
\hline & $\begin{array}{l}\text { 3. Improving training programs in accordance with the needs of competition of } \\
\text { Ukrainian companies in European energy markets. }\end{array}$ \\
\hline
\end{tabular}

Source: compiled by the authors for [4]

Table 3

Basic performance indicators functioning of the fuel and energy complex and its impact on the environment

\begin{tabular}{l|c|c|c|c|c}
\hline \multicolumn{1}{c|}{ Indicators } & 2015 & 2020 & 2025 & 2030 & 2035 \\
\hline $\begin{array}{l}\text { 1. Energy intensity of GDP, } \\
\text { kg.e.n / 1 \$ GDP }\end{array}$ & 0,33 & 0,27 & 0,23 & 0,20 & 0,17 \\
\hline $\begin{array}{l}\text { 2. Fuel consumption at TPPs } \\
\text { for sold electricity, g.p./kWh. }\end{array}$ & 396 & 384 & 367 & 353 & 334 \\
\hline
\end{tabular}


Continuation of table 3

\begin{tabular}{l|l|l|l|l|l}
\hline $\begin{array}{l}\text { 3. Level of residual resource of } \\
\text { fixed assets of fuel and energy } \\
\text { complex, } \%\end{array}$ & 20 & 30 & 50 & 60 & 80 \\
\hline $\begin{array}{l}\text { 4. Share of shunting capacities } \\
\text { of FEC power generation to the } \\
\text { total installed capacity, } \%\end{array}$ & 8,6 & 12 & 14 & 16 & 18 \\
\hline $\begin{array}{l}\text { 5. Share of losses in } \\
\text { distribution power grids, } \%\end{array}$ & 12 & 11 & 10 & 9 & 8 \\
\hline
\end{tabular}

\begin{tabular}{|c|c|c|c|c|c|}
\hline $\begin{array}{l}\text { 6. Share of exchange trade in } \\
\text { energy resources, } \% \text { of domestic } \\
\text { consumption, including } \\
\text { electricity, coal, oil, gas and } \\
\text { other fuels }\end{array}$ & 10 & 25 & 50 & 60 & 70 \\
\hline $\begin{array}{l}\text { 7. The share of renewable } \\
\text { energy sources in gross final } \\
\text { energy consumption, } \%\end{array}$ & 4,5 & 11 & 15 & 18 & 20 \\
\hline $\begin{array}{l}\text { 8. Share of local alternative } \\
\text { fuels in local fuel and energy } \\
\text { balances, } \% \text { of } \\
\text { consumption }\end{array}$ & & 10 & 15 & 18 & 20 \\
\hline $\begin{array}{l}\text { 9. Reduction of emissions in } \\
\mathrm{CO} 2 \text { equivalent to final fuel } \\
\text { consumption, } \% \text {, from } 2010\end{array}$ & & $>5$ & & $>15$ & $>20$ \\
\hline $\begin{array}{l}\text { 10. Reduction of specific } \\
\text { emissions in } \mathrm{CO}_{2} \text { equivalent in } \\
\text { the production of } 1 \mathrm{kWh}, \% \text {, } \\
\text { from } 2010\end{array}$ & & $>5$ & $>10$ & $>15$ & $>20$ \\
\hline $\begin{array}{l}\text { 11. Reduction of specific } \\
\text { emissions in } \mathrm{CO}_{2} \text { equivalent } \\
\text { during production } 1 \text { Gcal, } \% \text {, } \\
\text { from } 2010\end{array}$ & & $>5$ & $>10$ & $>15$ & $>20$ \\
\hline $\begin{array}{l}\text { 12. The share of capacity in } \\
\text { thermal generation that meets } \\
\text { EU environmental } \\
\text { requirements (emissions of } \\
\mathrm{SO}_{2}, \mathrm{NOx}, \text { ash), } \%\end{array}$ & & 20 & 40 & 80 & 100 \\
\hline
\end{tabular}

Source: compiled by the authors for [4]

Like any reform, this process requires a system of funding. Implementation costs (according to European practice) are divided into 2 categories - public sector costs and private sector costs. The first of them rely on the budget sphere, the second - on the funds of enterprises. In the composition of both, in turn, should be calculated three main components: administrative costs; investment (capital) costs; operating costs. The main focus is on investment costs related to the construction, reconstruction and modernization of facilities. 
An important problem is the need to quantify investment costs for Ukraine. In reality, in our opinion, macroeconomic comparisons and comparative approaches are really the only ones available. They are based on the analysis of European experts on the implementation of EU environmental requirements in Central and Eastern Europe. Its results (in terms of forecasting implementation costs in absolute terms and per capita) are shown in Table 4.

When evaluating the financial indicators shown in Table 4, it should be borne in mind that the timeframe for the implementation of EU environmental requirements is calculated in the range of 10 to 20 years. Among these countries, Poland and Romania are the most similar to Ukraine in terms of economic structure and population.

Table 4

Forecast of costs for the implementation of EU environmental requirements in Central and Eastern Europe

\begin{tabular}{l|c|c|c}
\hline \multicolumn{1}{c|}{ Country } & $\begin{array}{c}\text { Population, } \\
\text { million people }\end{array}$ & $\begin{array}{c}\text { Investment needs, } \\
\text { million euros }\end{array}$ & $\begin{array}{c}\text { Costs per } \\
\text { person, euros }\end{array}$ \\
\hline Bulgaria & 7,5 & 8610 & 1148 \\
\hline Latvia & 2,3 & $1480-2360$ & $643-1026$ \\
\hline Lithuania & 3,6 & 1600 & 444 \\
\hline Poland & 38,6 & $22100-42800$ & $573-1109$ \\
\hline Romania & 22,3 & 22000 & 987 \\
\hline Slovakia & 5,4 & 4800 & 889 \\
\hline Slovenia & 2,0 & 2430 & 1215 \\
\hline Hungary & 10,0 & $4100-10000$ & $410-1000$ \\
\hline Czech Republic & 10,2 & $6600-9400$ & $647-923$ \\
\hline
\end{tabular}

Source: compiled by the authors for [7]

With a certain conditionality, it is possible to estimate the projected costs of Ukraine for the implementation of $\mathrm{EU}$ environmental agreements in the amount of 1000-1100 euros per person and in general (for 10-20 years) - in 43000-47300 million euros. The share of Ukraine's fuel and energy sector in the total amount of harmful emissions into the atmosphere and other environments is expertly estimated at $40 \%$. Therefore, we can predict that the investments of the Ukrainian fuel and energy complex for its adaptation to environmental Euro requirements should amount to 17.2 to 18.9 billion euros in 10-20 years.

The analysis of actual environmental costs in Ukraine [2] taking into account the deflator index showed that, starting from 2000, there is a stagnation of environmental costs. Absolute funding for 
environmental protection in Ukraine is significantly less than 2 billion euros per year. This is clearly inferior to the level required to implement EU environmental requirements. Therefore, for Ukraine, especially for fuel and energy, a topical issue is (in addition to investing own funds of the budget and businesses) to attract assistance from EU funds, grants and international loans. After all, the implementation of EU environmental requirements (ie environmental clean-up and quality of life standards) is needed primarily by Ukraine, not the EU.

In general, it should be noted that at the governmental level the plans for the implementation of EU environmental requirements in terms of adaptation of domestic legal and regulatory requirements have been developed and approved in sufficient detail. However, the effectiveness of all work on the implementation of EU environmental requirements will be determined not only by the similarity of relevant regulations of Ukraine and the EU, but primarily by the increased level of investment of economic entities and budgets at all levels in environmental programs, effective control and monitoring, real dissemination of environmental management at the sectorial, regional levels and directly in economic entities. In the complex, these are the main components of the reform of environmental and regulatory means of influence to adapt the national fuel and energy sector to EU requirements.

\section{Conclusions}

1. Ecologically regulated optimization of the fuel and energy complex involves its restructuring on the principles of systemic minimization of the destructive impact of energy-producing technologies on the environment and its main element - man. Ecoregulated optimization should be a mandatory element of expert assessment of all fuel and energy projects in Ukraine. The main factors that inhibit the effective use of mechanisms of environmental regulation of the national energy complex are identified.

2 . In order to ensure the sustainable development of fuel and energy, the methodological principles of substantiation of investments in energy projects are formalized, which are a tool for analyzing the interaction of society and nature in carrying out production activities, which is inevitably accompanied by man-made environmental impact. Its use will facilitate the decision on the feasibility or inexpediency of implementing investment projects in energy production technologies. 
3. The level of innovation activity in the fuel and energy sector should be objectively assessed by the proposed system of so-called indicators that characterize the efficiency of the fuel and energy sector and its impact on the environment in accordance with EU requirements. The innovative model of Ukraine's fuel and energy sector development taking into account the requirements of environmental regulations requires a change in the system of government relations, strengthening the competence, activity and legal capacity of local authorities to solve environmental problems created by businesses located in the respective communities.

4. Practical recommendations for bringing the environmental regulations of the national fuel and energy sector to the requirements of the European Energy Society in terms of environmental and economic assessment of existing energy capacity and planned projects are proposed.

5. Euro-adaptation of the fuel and energy sector requires significant and consistent investment from economic entities, as well as budget support and financial assistance from the EU. Increased investment in environmental programs, effective control and monitoring, the use of environmental management at the sectorial, regional levels and directly by economic entities will ensure the process of reforming environmental regulatory tools for the European adaptation of national energy.

\section{References}

1. Moshchych S.Z. Organizational - managerial methods of ecological regulation and their application at the international and national levels. Global and national economic problems: electronic science. view. Mykolayiv National Univ. V.O. Sukhomlinsky. Mykolaiv, 2016.Issue 9. Pp. 553-558. URL: http://globalnational.in.ua/issue-9-2016. (appeal date: 25.02.2021).

2. BortnyukT.Yu., Moschich S.Z. Ecological optimization of the fuel and energy complex of Ukraine. Modern Transformation of Economics and Management in the Era of Globalization: International Scientific Practical Conference: conference proceedings, Lithuania, Klaipeda, 29 January, 2016. Klaipeda University, 2016. R. 52-55.

3. Reports on the implementation of state (national, target) programs. Ministry of Environmental Protection and Natural Resources of Ukraine: official website.URL: http://www.mepr.gov.ua/protection/protection5/261-zvity-provykonannia-derzhavnykh-tsilovykh-prohram. (appeal date: 25.02.2021).

4. Energy strategy of Ukraine for the period up to 2035. White Paper on Energy Policy of Ukraine "Security and Competitiveness". National Institute for Strategic Studies under the President of Ukraine. URL: http: 
//www.niss.gov.ua/public/File/2015_table/Energy\%20Snrategy.pdf. (appeal date: 25.02.2021).

5. Kovshun N.E., Melnyk O.M., Moschych S.Z. Problematic issues of national economy development in the context of sustainable development. Sustainable development - XXI century: management, technologies, models. Discussions 2017: collective monograph / Averikhina TV, Adamets TP, Anderson NV [etc.]; for science. ed. prof. Khlobystova EV; NTUU Kyiv Polytechnic. Institute named after Igor Sikorsky; Institute of Telecommunications and Global Inf. space of the National Academy of Sciences of Ukraine; Higher School of Economics and Humanities. Kyiv, 2017. P. 60-70.

6. Kushnir N., Kostrychenko V.Identification of the level of economic and ecological sustainability of agricultural land use in drainage conditions. 3 nd International Scientific and Technical Internet Conference "Innovative development of resource-saving technologies and sustainable use of natural resources". BookofAbstracts. - Petroșani, Romania: UNIVERSITAS Publishing, 2020. P. 256-258.

7. Mishchenko V. The EU "imposes" cleaner air and water on Ukraine, or the Environmental component of the Association Agreement with the EU. Mirror of the week. 2014. №12. URL: http: // gazeta.dt.ua/energy_market/yes-nav-yazuyeukrayini-chistishi-povitrya-ta-vodu-abo-ekologichna-skladova-ugodi-proasociaciyu-z-yes_html. (appeal date: 25.02.2021).

8. Moschych SZ Implementation of reorganization of the fuel and energy complex of Ukraine. Problems of rational use of socio-economic and natural resource potential of the region: financial policy and investment: coll. Science. wash. Kyiv: SEU; Rivne: NUVGP, 2015. №4. Pp. 89-97

9. Moschych S.Z. Methodology for assessing environmental risks in the system of environmental safety. Development of a new economy at the global, state and regional levels: materials International. scientific-practical Conf., Lviv, February 1920, 2016, Part 2. Lviv: LEF, 2016. P. 51-55.

10. Moshchych S. International experience in the application of methods of environmental regulation. International practice of socio-economic development of the country: problems and prospects: a collection of abstracts. works of participants International. scientific-practical conf. for students, graduate students and young scientists, Kyiv, December 18-19, 2015 Part 1. Kyiv: Analytical Center "New Economy", 2015. P. 133-135.

11. Moshchych S. Current state and problems of development of the coal industry of Ukraine. $3^{\text {rd }}$ International Scientific and Technical Internet Conference Innovative development of resource-saving technologies and sustainable use of natural resources. Book of Arstracts. Romania: 2020. P. 205-208.

12. Moshchych S, Levun O., Pylypchuk I. Energy efficiency management of the national economy. ${ }^{\text {rd }}$ International Scientific and Technical Internet Conference Innovative development of resource-saving technologies and sustainable use of natural resources. Book of Arstracts. Romania: 2020. P. 235-236.

13. Savina N.B., Malanchuk L.O., Ignatiuk I.,Z., Moshchych S.Z. Institutional basis and trends of managements of the use of the subsoil in Ukraine. Topical scientific researches into resource-saving technologies of mineral mining and processing . Multi-authored monograph. Sofia: 2020.P. 51-60. 